\title{
An Integrated Approach to Visioning for Peripheral Farming Villages: A Case Study of Japan
}

\author{
Michinori Uwasu ${ }^{1}$, Yukari Fuchigami ${ }^{1}$, Hiroyuki Takeda ${ }^{1}$, Tomohiko Ohno ${ }^{2} \&$ Shuji Kurimoto ${ }^{1}$ \\ ${ }^{1}$ Center for Environmental Innovation Design for Sustainability, Osaka University, Japan \\ ${ }^{2}$ Institute of Human and Social Sciences, Kanazawa University, Japan \\ Correspondence: Michinori Uwasu, 2-1 Yamadaoka, Suita. Center for Environmental Innovation Design for \\ Sustainability, Osaka University, Osaka, Japan. Tel: 81-6-6879-4150. E-mail: uwasu@ceids.osaka-u.ac.jp
}

Received: November 18, 2014 Accepted: January 14, 2015 Online Published: March 30, 2015

doi:10.5539/jsd.v8n2p282

URL: http://dx.doi.org/10.5539/jsd.v8n2p282

\begin{abstract}
This paper demonstrates a case study to comprehensively understand Japanese rural society, proposing an integrated approach to visioning sustainable rural society in the context of developed countries. We first provided an overview of Japanese agricultural history and conducted interviews with individuals regarding their life histories in two peripheral research fields in Japan. We then analyzed these life histories and compared them with the macro trends of agricultural policy. In particular, our analyses shed light on the interactions between agricultural policies, individuals' life and local resource endowments in rural areas. Specifically, human, natural and man-made capitals in Japanese rural society have changed in the way they are used while agricultural policies have exclusively focused on rice production. Based on the observation, we argue that Japanese policy might have hindered farmers' efforts and attempts in the country's periphery. We conclude that integrating macro analysis and field research facilitates the understanding of local resources and residents' wellbeing for conceptualizing and approaching the future of farming villages.
\end{abstract}

Keywords: rural society; periphery; integrated approach; visioning; local resources

\section{Introduction}

Population are aging in most developed countries and declining in some countries. Even when populations are stable, population tend to concentrate into cities and rural population are likely to decline. Yet, rural regions in the country side have rich cultural as well as natural resources, possessing heritageous and functional values. It is thus of critical importance to explore the way to envison future rural society for country's sustainability. This paper demonstrates an integral approach to visioning for rural society by looking into a Japanese case.

In Japan, the total amount of land - including grasslands, pasturelands, and fields - used for agriculture and forestry is approximately $80 \%$ in Japan, indicating that these are important sectors in the country (Ministry of Land, Infrastructure, Transport and Tourism, Japan [MLIT], 2014). Moreover, Japan is a mountainous country, and people residing in villages at the foot of or halfway up mountains rely on food from arable land on gently sloped surfaces, alluvial fans, and river terraces. These settlements, referred to as Nōsanson (rural farming and mountain villages), are located throughout Japan, including in peri-urban areas. Until the 1960s, Nōsanson residents cultivated crops on arable land while depending on the mountains for many of their daily necessities. It is possible to infer from historical documents that people lived diverse lifestyles according to their environment (e.g., Board of Ai Local History, 1998; Totsukawa Board of Education, 1961).

However, populations in agricultural villages are decreasing and the inhabitants are aging, particularly in Nōsanson. These villages generally no longer function well as cooperative bodies, and there is concern around the destruction of local capitals and the collapse of foundations needed for stable living. Studies in economic science addressed the need for restructuring Japanese agriculture with importance placed exclusively on economic efficiency (e.g., Hayami and Godo, 2002). On the other hand, field research has addressed the theme of dismantling and reorganizing the cooperatives of Nōsanson as well as the cooperative relationships surrounding regional resources (e.g., The Japanese Association for Rural Studies [JARS], 1998; Hayashi, 1992). This paper examined: 1) the history of rice policies and related measures using a top-down approach, and 2) the transformation of livelihoods and local people's views on local resources through a field study of Nōsanson 
using a bottom-up approach. The major contribution of this paper is to propose a new approach to understanding rural society. Specifically, we demonstrate that integrating the top-down approach and bottom-down approach facilitates to identify values of the resources in Nōsanson, which will be essential for constructing a sustainable rural society. This approach will enable us to analyze the interactions between political, human, and ecological factors. While a foundational collapse of stable living is the target concern of this paper, the authors intend to provide a platform for considering new methods of constructing future visions of rural societies.

Table 1. Conceptualizations for approaching rural society

\begin{tabular}{|c|c|c|}
\hline Approach/Method & Subject and focus & Objective \\
\hline $\begin{array}{l}\text { Top-down } \\
\cdot \text { Simulation } \\
\cdot \text { Statistical analysis } \\
\cdot \text { Policy analysis } \\
\end{array}$ & $\begin{array}{l}\text { Central, majority, and mainstream } \\
\text { Elites, average people } \\
\text { Production, consumption } \\
\text { Culture }\end{array}$ & $\begin{array}{l}\text { Holistic viewpoint focused on } \\
\text { understanding trends }\end{array}$ \\
\hline $\begin{array}{l}\text { Integration } \\
\cdot \text { Pilot project } \\
\cdot \text { Modeling } \\
\cdot \text { Participatory } \\
\text { workshop } \\
\cdot \text { Social design }\end{array}$ & $\begin{array}{l}\text { Interchange } \\
\text { Coexistence of diverse rural societies } \\
\text { Dynamic process } \\
\text { Co-practice }\end{array}$ & $\begin{array}{l}\text { Deriving implications for } \\
\text { conceptualizing and } \\
\text { approaching rural society }\end{array}$ \\
\hline $\begin{array}{l}\text { Bottom-up } \\
\cdot \text { Field research } \\
\cdot \text { Ethnography } \\
\cdot \text { Life history }\end{array}$ & $\begin{array}{l}\text { Local, periphery, and tributary } \\
\text { Remote areas } \\
\text { Specific, ordinary people } \\
\text { Livelihoods and lifestyles } \\
\text { Customs }\end{array}$ & $\begin{array}{l}\text { Understanding individuals' } \\
\text { wellbeing and local capitals }\end{array}$ \\
\hline
\end{tabular}

\section{Method}

Understanding cross-scale institutional linkages and the dynamics between people and resources is of high significance (Berkes, 2002), although surprisingly little research has been carried out. In this regard, we suggest that a theoretical framework that integrates both top-down and bottom-up approaches is essential for envisioning Nōsanson in a Japanese context (Table 1). First, the policies implemented by central and local governments may play a crucial role in envisioning a desirable society and the approach taken to realize this vision. Yet, policy results in various societal impacts through interactions between policy targets, policy makers, and other stakeholders. Focus should be placed on the enhancement of residents' wellbeing and thus, it is necessary to understand these interactions. Policy analysis can reveal the macro trends of economic and social situations through macroeconomic and societal statistics, which generally focus on production/consumption, industry, and culture. This approach is conducted from the viewpoint of authorities and elites to uncover policy impacts on individuals by looking at average people in society. On the other hand, fieldwork examines specific individuals and places and sheds light on the impacts that socio-economic transformation and policies will have on them.

In this study, we carry out a case study through field research in two places to demonstrate the valuations of local assets amassed in tangible and intangible spaces of a society. Field research can uncover the periphery for policy makers, such as the livelihoods and life histories of farmers in remote mountainous areas. While we acknowledge the significance of policy and governmental interventions, the bottom-up approach provides useful lessons for the top-down approach and policymaking (National Graduate Institute for Policy Studies [GRIPS], 1998). Moreover, without the ground level approach, it is difficult to understand the degree and kind of capitals that exist within a community. We argue that it is necessary to integrate top-down and bottom-up approaches for conceptualizing and approaching rural society. Local people in Nōsanson have more knowledge of local resources while policy makers from central/local governments understand economic macro trends and possess greater access to financial and human resources. However, these two do not interact when solutions and visions are individually proposed. Therefore, it is necessary to bridge these two viewpoints in order to implement pilot projects and create role models, participatory workshops, and social designs, all of which involve dynamic processes and interactions among different stakeholders. 


\section{History of Agricultural Policy}

\subsection{Transitions in Nōsanson Regarding Agricultural Policies}

This section provides an overview of the history of agricultural policy in Japan. Table 2 summarizes the transitions and characteristics agricultural policies/countermeasures in Nōsanson. During World War II, the Japanese government controlled resource allocations to assure sufficient food production, and the Staple Food Control Act of 1942 was established as one such measure. After the war, Japan suffered severely from a chronic rice shortage due to the devastation of agricultural infrastructure and lack of human resources. Under the Staple Food Control Act, the government purchased rice crops directly from farmers and sold them to citizens (referred to as the wholesale purchase system). This method was effective for managing the supply and demand of rice, a staple food in Japan, and thus continued after the war. The Fundamental Law of Agriculture established in 1961 promoted the modernization of the agricultural production system. The government's guarantee to purchase all rice products induced incremental investments, and agricultural production substantially increased.

Meanwhile, Japan's rapid economic growth diversified food preferences and hence, rice consumption started to decline in the mid 1960s. Rice stocks surged under the Staple Food Act and by the early 1970s it became difficult to maintain the wholesale purchase system. Moreover, oil shock struck the world economy in 1973 and the United States announced an embargo on soybean products. The Japanese government addressed food security by promoting a shift from rice to soybean and wheat crops in an attempt to raise the food self-sufficiency rate.

Table 2. Transitions and characteristics of Nōsanson and agricultural policies and countermeasures

\begin{tabular}{|c|c|c|}
\hline $\begin{array}{l}\text { Development stage } \\
\text { (period in Japan) }\end{array}$ & $\begin{array}{l}\text { Characteristics of rural and agricultural } \\
\text { societies }\end{array}$ & Major policy and countermeasure \\
\hline $\begin{array}{l}\text { Less developed } \\
\text { (mid-1940s to } \\
\text { mid-1950s) }\end{array}$ & $\begin{array}{l}\text { - Eradication of poverty } \\
\text { - Stable food supply }\end{array}$ & $\begin{array}{l}\cdot \text { Land redistribution } \\
\text { - The Staple Food Control Act } \\
\text { (governmental purchase of rice) }\end{array}$ \\
\hline $\begin{array}{l}\text { Transitory I } \\
\text { (mid-1950s to 1970s ) }\end{array}$ & $\begin{array}{l}\text { Food security } \\
\text { - Reduction of the income gap between } \\
\text { rural and urban areas } \\
\text { - Growth in agricultural productivity }\end{array}$ & $\begin{array}{l}\text { - Fundamental Law of Agriculture and } \\
\text { Cooperatives (minimum-pricing } \\
\text { standard) } \\
\text { - Investment in infrastructure } \\
\text { - Import taxes and quotes }\end{array}$ \\
\hline $\begin{array}{l}\text { Transitory II } \\
\text { (1980s to } 1990 \mathrm{~s})\end{array}$ & $\begin{array}{l}\text { - Excessive agricultural production } \\
\text { - Structural adjustment (trade problems) }\end{array}$ & $\begin{array}{l}\text { - Trade liberalization (e.g., beef, } \\
\text { oranges) through participation in } \\
\text { GATT } \\
\text { - The Stabilization of Supply, Demand, } \\
\text { and Prices of Staple Foods Act } \\
\text { (reducing the rice acreage policy) }\end{array}$ \\
\hline $\begin{array}{l}\text { Developed } \\
\text { (2000s to present) }\end{array}$ & $\begin{array}{l}\text { - Aging and depopulation of rural } \\
\text { communities (sustainable rural } \\
\text { communities) } \\
\text { - Budget deficit } \\
\text { - Strengthened agricultural } \\
\text { competitiveness } \\
\end{array}$ & $\begin{array}{l}\text { - Land aggregation policy } \\
\text { - Program-oriented policy } \\
\text { - (Free Trade Association, land and } \\
\text { institutional reforms, open to } \\
\text { agricultural firms) }\end{array}$ \\
\hline
\end{tabular}

The 1980s saw the evolution of Japanese industrial sectors and a rise in exports of Japanese manufactured products. Increasing pressure from foreign countries influenced Japan to agree to the GATT (General Agreement on Tariffs and Trade) Uruguay Round in 1993, aimed mainly at reducing agricultural subsidies and trade barriers. In effect, Japan opened the market for most agricultural commodities and products, such as beef and oranges (but excluding rice) in 1995. Accordingly, the Staple Food Control Act was replaced by the Act on Stabilization of Supply, Demand, and Prices of Staple Food, which caused a significant shift in rice policies. In principle, the government no longer purchased rice products from farmers and rice distribution went through markets. In addition, local famers were then allowed to participate in the production adjustment process so that motivated farmers could continue rice production. After the abolishment of the Fundamental Agricultural Law in 1999, the Food, Agriculture, and Rural Areas Basic Act was launched. This Act followed a series of agricultural 
land-aggregation measures through the integration of rice paddy fields in order to raise productivity, and used abandoned arable land to cultivate soybean, wheat, and rice as livestock feed in response to decreased rice consumption (Ministry of Agriculture, Forestry, and Fishery [MAFF], 2007).

\subsection{Agricultural Promotion Awards as Another Japanese Agricultural Policy Approach}

One of the roles of agricultural policy is to establish a desirable agricultural production system in response to temporal and environmental changes by adjusting land size, institutions, and crop selection (Norton, Alwang, \& Masters, 2010). A unique approach taken in Japan is the Award Program, which started in 1962 to select role models for desirable agricultural production systems. In 2005, 510 cases were provided commendation by the Ministry of Agriculture, Forestry and Fisheries. Among these, three were selected to receive one of three awards - the Emperor's Cup, Prime Minister's Award, and Agriculture, Forestry, and Fisheries Promotion Award.

The National Library possesses records of past winners of these three awards. We reviewed the reports from 1965 to 2010 and analyzed them according to their production system. The number of winners is 30, of which ten are rice-producing farmers. Ten cases are awarded for non-rice farming while still producing rice, and four of the ten awarded cases did not incorporate any rice production. In particular, no rice production cases are selected in years when production adjustment started (1970), and when oil shock triggered the food security dispute (1973). Soy-paste producers are frequently recognized in these years, perhaps because the government intended to promote soybean production. As for ownership, 15 cases are household farmers and 15 are collective farmers. Among the 27 winners (excluding soy-paste producers), 23 are compound farmers - only four cases involve farmers who produced single crops or rice-wheat crops.

Japan is by no means a rice country - rice paddy fields are seen in every part of Japan and a substantial proportion of farmers pursue rice production. However, as far as the Agricultural Promotion Award is concerned, only one case was awarded for rice production and most cases involved compound farmers. However, the reality is that the food self-sufficient rate has recently been only around $40 \%$ while the rice self-sufficiency rate has been $100 \%$. This means that farmers have focused exclusively on rice production in Japan and hence, large gaps exist between agricultural policy (aimed at compound production) and agricultural management. We posit that the regime under the Staple Food Control Act created this gap. The government's direct purchase of rice for higher prices than those in the market continued until 1995. Even households whose main incomes were generated from employment were encouraged to pursue rice production with no incentive to shift towards this crop. In the 1950s, the imperative challenge was to increase the staple food supply, and in the 1960s, Japan faced increasing income gaps between urban and rural residents. The Liberal Democratic Party, then the administration, kept the feed-in-tariff system to receive collective support from farmers. Yet, this gap created a large deficit for maintaining rice stocks while strong pressure in favor of trade liberalization continued, which led to the end of the feed-in-tariff policy.

\section{Field Research: Oral Histories of Individual Farmers in Peripheral Nōsanso}

\subsection{Field Research in the Periphery}

Japanese Nōsanson are often referred to as non-Densely-Inhabited-Districts, and are categorized as either peri-urban communities, plain communities, intermediate communities, or mountain communities depending on their location and geographic features (MLIT, 2013). Peri-urban communities are located in suburban areas and include a high proportion of non-farming households. Plain communities are most suitable for farming practices due to their abundant land resources, and the Japanese government considers agriculture in plain communities as role models. Mountain communities are the smallest in both population size and agricultural productivity due to their geographical characteristics, but account for 50\% of Japan's land (Ministry of Internal Affairs and Communications [MIAC], 2012).

Social population decreases and an aging population have caused the marginalization of mountain communities with people abandoning farmlands and forest maintenance, while a large proportion of farmers in peri-urban areas have simultaneously disappeared during the process of urban development. It is natural that urbanization and the country's demographic changes caused these transformations, but the uniform (rice-focused) Japanese agricultural polices likely reinforced the effects. In particular, Japanese policy has focused exclusively on the agricultural majority in plain and intermediate communities. However, we believe that even the peripheries of Nōsanson (i.e., mountainous communities) possess agricultural diversity and the potential to develop, thus the marginalization of communities means the loss of agricultural and cultural diversity throughout Japan.

While envisioning the future for a rural society, these communities should be carefully considered. If we apply only an economic rationality, then these peripheral communities would be the first candidates to be abandoned. 
Nevertheless, we believe that the derived lessons and knowledge are essential for envisioning the future of rural societies. First, deliberation is required over what criteria should be employed to discuss budgetary pullout in public policy. Though economic indicators are important criteria, they are not the sole factors. Second, we have to keep in mind that once these diverse communities become extinct, it will be nearly impossible or extremely costly to recover them. This indicates the need to understand individual experiences and views and the diversity of rural society in Japan, which was done through fieldwork in two research fields of peripheral Nōsanson. Third, these communities often play a crucial role in the provision of important ecosystem services such as flood control through forest conservation particularly in Japan. Thus increasing abandoned communities potentially incur large social costs. In this study, we conducted interviews in these peripheral communities and reported the summary of the oral-history survey.

Table 3. Fields research statistics

\begin{tabular}{ccc}
\hline & Kannogawa District & Ai District \\
\hline Location & Totsukawa village, Nara & Ibaraki city, Osaka \\
Community type & Mountainous & Peri-urban \\
Number of interviewees & 19 & 3 \\
Interviewee's average age & 69.7 & 80 \\
Main occupation & Pension, employment & Pension and agriculture \\
Date of interview & February 2014 & March 2014 \\
\hline
\end{tabular}

\subsection{Survey Results}

Figure 1 and Table 3 present the location and information of the two research fields, respectively. Kannogawa District in Totsukawa village represents a mountainous community. Kannogawa is a small, mountainous hamlet in the vast village located in the southern part of Nara Prefecture, Japan. 95\% of the land in Kannogawa is mountainous with very limited arable land, and home to 33 households. We conducted interviews at Kannogawa in February 2014 with 19 inhabitants. As of February 2014, the district included 33 households with 63 people. In the past, the inhabitants practiced agriculture and were hired in the forestry industry. Due to the demand for labor, people from outside of the district were also a part of the labor force during the 1950s. After the decline of the forestry industry, many households became engaged in construction or were hired outside of the district (e.g., bus drivers, public officials, etc.). At present, the national pension is the main income source for most people, and cultivating farmland for self-consumption helps make ends meet. Most children and younger generations live outside the district; only in three households do children and parents live together. However, we learned through the interviews that the residents have come to realize the value of their lifestyles and customs through interactions with young visitors from cities. For example, running lodges is an effective means to revalue the capitals buried in the landscape. Many of the interviewees expressed their home royalty and life satisfaction. It became evident that the construction of a system that capitalizes on buried local resources could lead to the revitalization of the community.

On the other hand, Ai District is a peri-urban community located in the suburbs of Ibaraki City, Osaka Prefecture. The district was a center for poppy production in Japan with more than one hundred farmers in the early 1900s. After World War II, Japan's rapid economic growth led to the construction of large amounts of houses and factories in suburban areas, transforming rice paddies and forests into houses, apartments, plants, and schools. However, farming is still extensively practiced in the district compared to other suburban areas in Osaka Prefecture, and the district has preserved a landscape full of rice paddies. We interviewed three inhabitants, one in his sixties and two in their eighties. Agricultural management was no longer their primary income source due to retirement, but they continued to farm for self-consumption. 


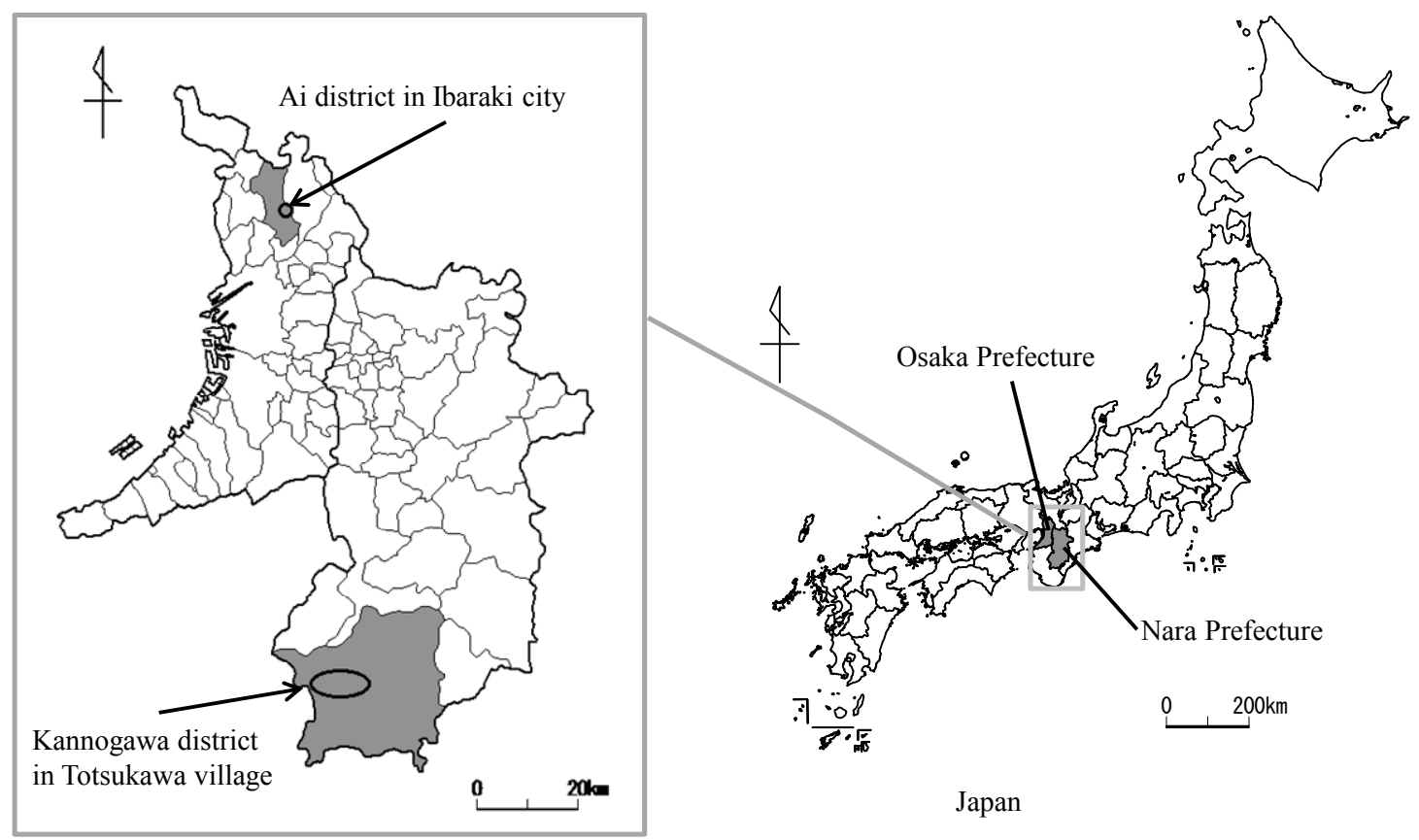

Figure 1. Field Research Locations

Table 4. External (policy) impacts on peripheral farming

\begin{tabular}{lll}
\hline External impacts & Positive influences & Negative influences \\
\hline Rice-focused policy & (U) High price standard for rice & \\
$\begin{array}{l}\text { Macroeconomic } \\
\text { changes, trade } \\
\text { liberalization }\end{array}$ & $\begin{array}{l}\text { (M) Investment in infrastructure, } \\
\text { including roads and irrigation }\end{array}$ & $\begin{array}{l}\text { (M, U) Fall in relative prices of } \\
\text { agricultural products }\end{array}$ \\
& $\begin{array}{l}\text { (M, U) Reduced input prices for } \\
\text { fertilizer and machinery, etc. }\end{array}$ & (M) Development pressure \\
& $(\mathrm{M}, \mathrm{U})$ Establishment of social security & (M) Decline in forestry and communities \\
& & (U) Outflow of population \\
& (U) Decrease in prices of non-rice \\
& agricultural products, leading to less \\
& income
\end{tabular}

Note: "M" and "U" in parentheses denote urban peripheral and mountainous peripheral areas, respectively. This framework is counstructed based on Mitsumata (2013).

Despite the generational differences, we found common characteristics regarding respondents' lifestyles and views of farming. The main reason for their career selection (agriculture) was the attractiveness of agriculture and the rice paddy landscape in the district, which is distinct from neighboring districts. They all stated in their interviews that they devised means to make ends meet and all practiced compound agriculture producing rice and a variety of vegetables. They claimed that rice is by far the most important crop because it can be stored for long periods of time and can be used to make cash when necessary. In summary, of the 23 interviewees, 15 were male and eight were female. The average age was 69.5 years old (the youngest was 52), indicating the degree of aging in the district. Many inhabitants engage in agriculture for self-consumption while their household income is generated through either pension or employment. Most younger generations (the interviewees' children) live outside Kannogawa District. 


\section{Discussion}

\subsection{Impacts of Macroeconomic Change Regarding Japanese Agricultural Policy}

As discussed in Section 3, a large shift has occurred in the Japanese economy and surrounding environments for Japanese farms in the past 50 years. We attempted to link the external impacts and subjective perceptions of farmers in peripheral Nōsanson. Table 4 summarizes the external impacts on farmers in urban and mountainous peripheral areas.

Japanese agricultural policy has focused on rice production by setting up high price standards for rice. This policy has brought merits for individual farmers in general: a high price of rice increases and stabilizes the household income of farmers. However, most farmers in mountain peripheries produce rice for self-consumption, and thus it creates little positive influence for them. During the 1970s, rapid economic growth brought large investments in infrastructure (e.g., roads and irrigation), and the diffusion of agricultural technologies such as high-yield crop varieties and chemical fertilizers, which are clearly beneficial to ordinary farmers in peripheral areas. Economic growth was also associated with the free trade policy in Japan, but it generally negatively influenced mountain Nōsanson. Decreased timber prices caused a decline in the forestry industry in the 1960s, which accelerated population outflow. Trade liberalization of agriculture in the 1990s resulted in lower prices for many agricultural products, which adversely influenced compound farms in peri-urban Nōsanson. In the meantime, economic growth increased land development pressure in urban peripheral areas, thus the number of farms and agricultural land substantially decreased in peri-urban areas.

Te interviews carried out in Kannogawa District of Totsukawa village and Ai District of Ibaraki City provide insight into the external impacts on individual lives. Generally, farmers in peri-urban and mountain communities face inflexible constraints of limited arable land and much less support from governments. However, our interviews and analyses revealed that individual farmers attempted to maximize their knowledge and available resources to maintain agricultural production as an income source regardless of their location. Individual farmers in peripheral Nōsanson possessed strong attachments and affection for their locales and responded to the changing environment by finding ways to make ends meet. The problem is that Japanese agricultural policies have ignored the diversity of agriculture and Nōsanson. They have set up national targets and standards, such as increasing the food self-sufficiency rate, while high rice prices and corresponding policies exclusively consider agriculture in plain Nōsanson. Thus, one important consideration should be how policies and other measures address the diversity of agriculture. In a society that faces an aging and shrinking population, economic efficiency becomes the first criterion for decision making due to increasing budgetary pressure, and other factors tend to be ignored. However, diversity in agricultural systems and landscapes should be considered as an important indicator for sustainable societies. In a research context, collaboration among researchers to demonstrate co-practice and social design will be essential for the conceptualization and implementation of feasible measures.

\subsection{Capitalizing on Local Resources}

Our survey in two peripheral Nōsanson revealed that different forms of capital still exist and have not changed in terms of volume or type, although they have changed in the way they are used, which has improved the quality of capital but is accompanied by growing dissatisfaction with it. For example, forests in Kannogawa District continue to exist in abundance as physical stock, but the decline in demand for timber and shortage of manpower to carry out forestry work suggests that it has changed in terms of its utilization and management. Even in rural societies such as Kannogawa District, the primary purpose of forest utilization has shifted from direct utilization toward indirect utilization (water source cultivation, landscaping). The quality and quantity of man-made capital in both districts is much higher now than it was in the past. However, while the convenience of daily life has improved, the modernization process has also led to rising demands in man-made capital standards, and so they are no longer regarded as satisfactory by local residents. As for human/social capital, the cooperation that takes place in occupational activities and in the management of shared capitals has held much significance until now in peripheral Nōsanson. However, the continuing decline in the birth rate and aging population has meant that this cooperation now takes the form of mental/emotional support whereby residents live a communal life.

We also found through the survey that interactions among these different types of capitals influenced residents' welfare, safety, and level of happiness. This is particularly true in mountain Nōsanson. For example, Kannogawa often becomes isolated as a result of natural disasters, but since residents purchase goods in bulk during non-emergency times and engage in self-consumption farming, they have the capacity to maintain their daily lives for nearly half a month after a disaster strikes. Local knowledge about disasters (wisdom), which is a means of disaster preparedness, can be considered a form of intangible capital amassed through a long history of 
disasters. On the other hand, the functional decline of the fire brigade and forestry workers' collective resulting from the declining birth rate and aging population has negatively affected daily forest management and emergency restoration of roads affected by flood disasters. This demonstrates how intangible capital adversely affects man-made capital and natural resources. In fact, the survey revealed that residents have a high degree of satisfaction with their current way of life, citing their fondness for the land and close-knit, stable interpersonal relationships (intangible capital).

\section{Concluding Remarks}

This paper attempted to integrate macro policy analysis with field surveys in peripheral regions to understand rural society in the developed country's context through a case study of Japan. We first provided an overview of the history of agricultural policy regarding socioeconomic transitions in Japan. To overcome rural and agricultural challenges, Japan's agricultural policy has focused on rice production with an emphasis on farmers in the plain region as a role model. Yet, Japan is now facing new challenges to Nōsanson: farmers with side jobs have become the majority in the agricultural sector, even in the plain communities of Japan; a lack of farming successors is becoming more and more serious in all Nōsanson; and agriculture in the plain region has not increased its competitiveness. We carried out interviews in peri-urban and mountainous Nōsanson, which are large land areas with diverse farming systems, and found that farmers in peripheral Nōsanson are disadvantaged when it comes to agriculture because they are tributaries for agricultural policy and face agricultural resource limitations. However, we argue that it is important to maintain the diversity of Japanese Nōsanson in the future. Our survey revealed that substantial amounts of local capitals exist in peripheral Nōsanson and interactions among these different types of capitals influence people's wellbeing, who are motivated and still practice farming. Identifying and valuing local resources as capital is perhaps a first, but necessary step toward conceptualizing and approaching Japanese Nōsanson.

\section{Acknowledgments}

The authors are grateful to the Totsukawa Village Office and survey participants in Kannogawa District and Ai District in Japan for their great support.

\section{References}

Berkes, F. (2002). Cross-scale institutional linkages: Perspectives from the bottom-up, In E. Ostrom, T. Dietz, N. Nives Dolsak, C. P. Stern, S. Stonich, \& E. U. Weber (Eds.), The drama of the commons, Committee on the Human Dimensions of Global Change (p.294). The National Academies Press, Washington DC, USA.

Board of Ai Local History. (1998). History of Ai, Board of Ai Local History, Ibaraki (in Japanese).

Hayami, Y., \& Godo, H. (2002). Agricultural Economics. Iwanami Shoten, Tokyo, Japan.

Hayash, H. (1993). Totsukawa investigation record: Folk traditions 2. Education Board of Tostukawa village, Daiichi-hoki Press, Tokyo, (in Japanese).

Ministry of Agriculture, Forestry, and Fishery, Japan (MAFF). (2007). Annual Report on Food, Agriculture, and Rural Areas in Japan. Retrieved from http://www.maff.go.jp/j/wpaper/w_maff/h24/pdf/e_all.pdf

Ministry of Internal Affairs and Communications, Japan (MIAC). (2012). White Paper on Information and Communications 2012. Retrieved from http://www.soumu.go.jp/johotsusintokei/whitepaper/eng/WP2012/2012-index.html

Ministry of Land, Infrastructure, Transport and Tourism, Japan (MLIT). (2014). Summary Paper on White Paper on Land 2013. Retrieved from http://tochi.mlit.go.jp/english/white-paper/land-white-paper

Mitsumata, G. (2013). Complementary environmental resource policies in the public, commons, and private spheres: An analysis of external impacts on the commons. In T. Murota, \& K. Takeshita (Eds.), Local Commons and Democratic Environmental Governance. United Nations University Press, Tokyo, Japan.

National Graduate Institute for Policy Studies (GRIPS). (1998). Oral History as Policy Studies, Chuo Koron-sha, Tokyo, Japan.

Norton, G. W., Alwang, J., \& Masters, W. A. (2010). Economics of Agricultural Development (2nd ed.). Routledge, London.

Ohno, A. (2005). Introduction of mountain village environment sociology: Changing to marginal hamlet and watershed co-management in modern mountain village. Rural Culture Association Press, Tokyo, Japan.

Ostrom, E. (1999). Governing the commons - the evolution of institutions for collective action. Cambridge University Press, Cambridge, UK. 
The Japanese Association for Rural Studies (JARS). (1998). Annual Bulletin of Rural Studies (Vol. 34). Nobunkyo, Tokyo, Japan.

Totsukawa Board of Education. (1961). Totsukawa Cultural Records. Totsukawa, Japan (in Japanese).

\section{Copyrights}

Copyright for this article is retained by the author(s), with first publication rights granted to the journal.

This is an open-access article distributed under the terms and conditions of the Creative Commons Attribution license (http://creativecommons.org/licenses/by/3.0/). 